\title{
For Goodwill, Aid and Economic Growth: The Funding of Academic Exchange Through the Swedish Institute, 1945-2010
}

\begin{abstract}
Andreas Åkerlund
Abstract

The article investigates the financial basis of state-sponsored international academic exchange through the Swedish Institute (SI). Founded in 1945 the SI is the main institution for Swedish public diplomacy and is as such part of modern foreign policy and Swedish soft power. This article maps the changing sources of funding as well as the sums spent on academic exchange from 1945-2010. It also discusses the various forms of exchange programs and gives an overview of the ideas behind and arguments for such programs. The overall picture is that state-sponsored exchange after 1945 has expanded. Not only has more and more money been spent on exchange, which led to an increase in the number of persons benefitted, but there has also been a diversification in exchange schemes towards parallel programs, each designed to fulfill a certain task. Though they fund different parts of the SI exchange scheme, the main sources of funding, however, have remained the same: the Ministry for Foreign Affairs, various development assistance agencies and programs as well as the Ministry for Education.
\end{abstract}

Keywords

public diplomacy, internationalisation, exchange financing, scholarships, official development assistance

\section{Introduction}

How do money and financial matters affect educational and scholarly exchange? Since money is a key pre-requisite for travel in general as well as for studies and scholarly work, this is a fundamental question. The exact relationship between financiers and recipients, between funding bodies and selected scholars has however not yet attracted much attention. There are several reasons for this. One is that exchange is situated at the intersection of different research fields, namely between research on internalisation of education, international philanthropy and public diplomacy. Especially the latter has often been concerned more with the policies and strategies behind various state-sponsored exchange programs than with the financial basis of such programs and their effects on the flows of individuals over the globe. ${ }^{1}$ On the

1 Examples of such policy oriented studies are Liping Bu, "Educational Exchange and Cultural Diplomacy in the Cold War," Journal of American Studies 33, no. 3 (1999); Christopher Medalis, "The Strength of Soft Power: American Cultural Diplomacy and the Fulbright Program during the 1989-1991 Transition Period in Hungary," AUDEM: The International Journal of Higher Education and Democracy 3 (2012) or Alessandra Bitumi, "Building Bridges across the Atlantic: the European

Andreas Åkerlund, PhD, is a Researcher in History at the Department of History, Uppsala University, Sweden.

Email: andreas.akerlund@hist.uu.se 
other hand, recent research into the internationalisation of higher education often lacks a historical perspective, and not least important, the tools to work with historical sources, which are necessary to understand the development and long term impact of exchange programs. ${ }^{2}$

There are various challenges when researching the field of scholarly exchange. One challenge is the sheer number of funding bodies - that is foundations, professional associations and various forms of state-funded initiatives. Each funding body has different aims, rules and funding practices so investigating the various forms of financing exchange without concentrating on one organisation, or at least one type of organisation, is difficult. Another challenge is the necessity to research relatively long periods of time in order to identify continuities and changes. The impact of changing funding practices is only visible when looking at the development over several decades or more. Before it will be even possible to make conclusions about this field as a whole, various case studies into different organisations will be necessary. This article presents one such case study of the Swedish state-funded scholarships for foreigners between 1938 and 2010. It is based on the assumption that in order to understand the relationship between policy and its outcome - the international movement of scholars - it is necessary to explain the complex relationship between policy, the organisational makeup of the institution responsible for exchange, the origin and uses of state funding and the practice of scholarship programs. In the end such organisational matters determine not only how many foreign academics are allowed to enter the country through various programs, but also to some extent their origin and field of study. The long-term perspective makes it possible to see changes over time in funding policy, scholarship types and groups of scholars targeted by different programs through the years.

In short, this article is concerned with the following questions: Why is scholarly exchange being funded by the state at any given time? How is this visible in the availability of certain forms of financing throughout history? This correlates with the question: What is being financed? If exchange and the money invested in it are subject to politically motivated changes it is likely the forms of exchange are as well. This article is an explorative overview, which contains no in depth studies of decision processes or political debates, but instead sets out to map the long development lines of Swedish exchange funding from before the Second World War until the present.

The institution which will be investigated in this article is the Swedish Institute (SI) which was founded in 1945 and is still in existence. Since its founding SI has administered state-funded exchange programs targeted at foreign scholars. The best source for scholarship funding from 1945 until today are therefore the SI yearly economic reports, which are the main source material for this article. A simple quantitative overview of exchange funding through this institution is found in Figure 1,

Union Visitors Program. A Case Study for Public Diplomacy and the Transatlantic Relationship in the 1970s," The International History Review 35 no. 5 (2013). Some basic numbers on US exchange funding for 1981 are provided in Kevin V. Mulcahy, "Cultural Diplomacy and the Exchange Programs: 1938-1978," The Journal of Arts Management, Law, and Society 29 no. 1 (1999), 22, but they are not put into any larger budgetary context.

2 See for instance the rudimentary history presented in: Terri Kim, "Shifting Patterns of Transnational Academic Mobility: A Comparative and Historical Approach," Comparative Education 45 no. 3 (2009). 
where roughly every fifth budgetary year has been evaluated in order to provide an image of the general development. ${ }^{3}$

Figure 1. Exchange cost development (amount and ratio)

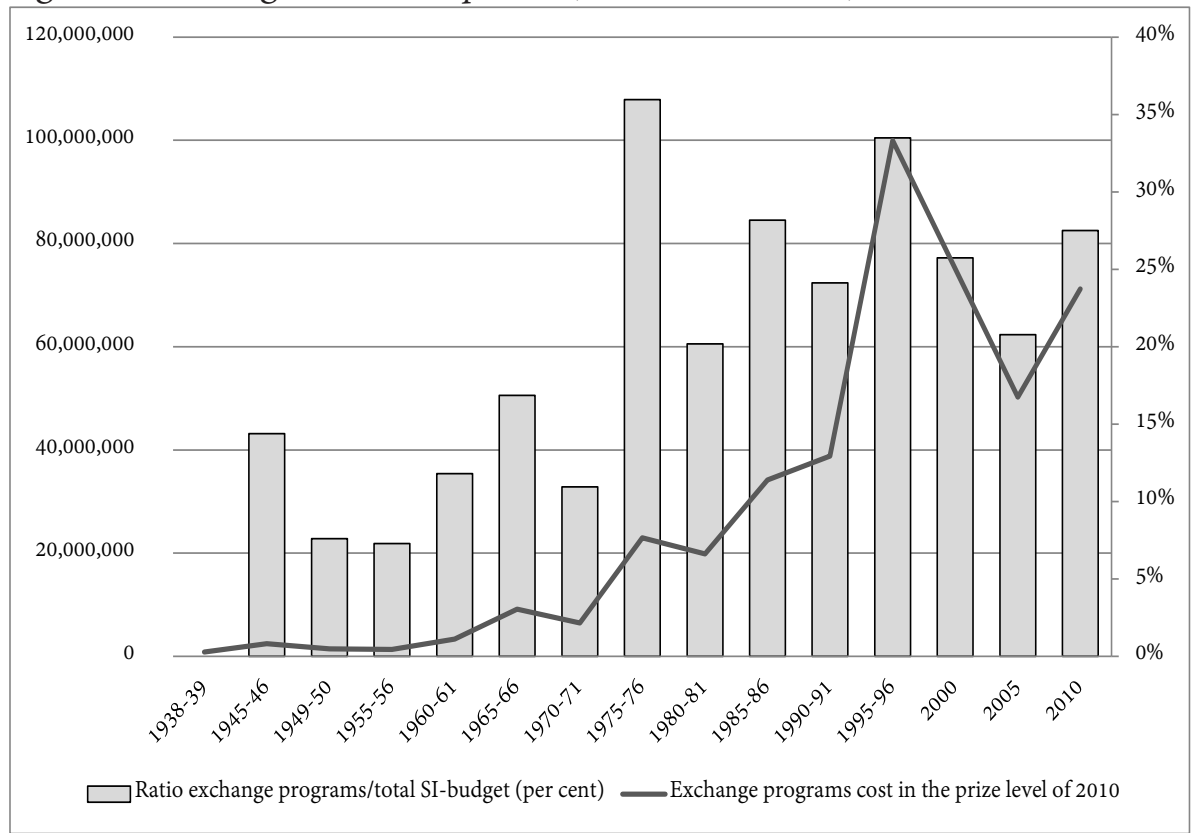

Amount spent on academic exchange through the SI (1938: through the Ministry for Foreign Affairs) as a percentage of the SI total budget.

Sources: I 798, UD, RA; SI, Verksamheten 1945-46; SI, Verksamhetsberättelse 1949-50; SI, Svenska Institutet 1955-56 (BVII, vol. 1, Hemmamyndigheten, Svenska Institutet, RA); SI, Svenska Institutet 1960-61; SI, Svenska Institutet 1965-66 (BVII, vol. 2, Hemmamyndigheten, Svenska Institutet, RA); SI, Verksamheten 1970-71; SI, Verksamhetsberättelse budgetåret 1975-76 (BVII, vol. 3, Hemmamyndigheten, Svenska Institutet, RA); SI, Verksamhetsberättelse budgetåret 1980-81 (BIA, vol. 1, Hemmamyndigheten 2, Svenska Institutet, RA); SI, Verksamhetsberättelse 1985-86 (BIA, vol. 3, Hemmamyndigheten 2, Svenska Institutet, RA); SI, "Resultatanalys verksamhet 1987/88-1991/92," (internal report from the Swedish Institute, 1992); SI, Verksamhetsredovisning 1995/96; SI, Årsredovisning 2000; SI, Årsredovisning 2005; SI, För Sverige i världen: Svenska Institutets årsredovisning 2010.

There are two basic points which can be made by looking at this chart. The first is that the state has increased its investment in scholarly exchange over the years. In particular, the 1970s and the 1990s were decades of increased investment in scholarly exchange as shown by the line. This becomes even clearer when looking at the bars, which show the ratio between the yearly spending on exchange programs related to the overall spending of the institute. Here the 1970s and 1990s stand out even more. In 1975/76 over 35 per cent of the institute's total spending was devoted to exchange programs and in 1995/96 spending is slightly under 35 per cent. In addition, compared to surrounding years the budgetary years of 1945/46 and 1965/66 also stand out as years of increased spending. Another general comment is that after 1990

$31938 / 39$ is the starting point as this was the first year scholarships were awarded. 1945/46 was chosen as the first normal budgetary year for the SI after WWII. 1949/50 was chosen over 1950/51 as this particular year is lacking in the SI archive. When SI was turned into a state agency in 1998 the budgetary year was changed from a broken year (July-June) to the calendar year. 
the Swedish state began spending a significant amount more on scholarly exchange then before this time.

Apart from indicating a continuous rise in state assets invested in academic exchange; Figure 1 also shows us that the rise has not been linear. Instead, it consists of a number of steps or periods of rapid expansion. This general development will be explained through mapping the various forms of state financing of academic exchange and putting them in a political context. This means looking at the motives behind financing, the forms of grants as well as the relationship of the state grants to each other and the SI budget as a whole. The impact of this financing system on the composition of the group of incoming scholars will not be investigated as this investigation would be too large for a single article. Preliminary results on the relationship between changes in foreign policy and groups of incoming scholars have been published elsewhere. ${ }^{4}$

\section{The origins of the scholarship system and the establishment of the Swedish Institute}

The funding of Swedish state scholarships can be traced back to 1938 in large part due to the establishment of the Enlightenment Board (Upplysningsnämnden) in 1935. This board consisted of persons from the Ministry for Foreign Affairs and The Ministry of Education as well as representatives elected by the Culture Council (Kulturrådet). Represented in this Council were a large number of civil society actors. Organisationally, the board was part of the Ministry for Foreign Affairs' press department. ${ }^{5}$ In 1938, the board suggested the creation of scholarships for foreigners motivated by the fact that a few countries had already opened their scholarship programs to Swedes and additional countries had promised to offer Swedish citizens scholarships on the basis of reciprocity. In their proposal the board argued that such a program would help spread knowledge about Sweden abroad which would benefit the international image of the country. For this reason the rules stated that anybody studying Swedish language, history, literature, law or society would have priority to the scholarships. ${ }^{6}$ Funds were assigned for a total of 21 scholarships for the academic year 1938/39: two scholarships each for Denmark, Finland, Norway, England, France, Czechoslovakia and Germany and one each for Iceland, Italy, Poland and Hungary. $^{7}$ In addition to these 18 regular, bilateral scholarships, extra funds were assigned to one unilateral scholarship each for Estonia, Latvia and Lithuania. ${ }^{8}$ The total cost for the program was 32,000 Swedish crowns.

4 Andreas Åkerlund, "Utrikespolitik och internationellt utbyte: Svenska statsstipendier som offentlig diplomati 1938-1957, “ in Allt på ett bräde. Stat, ekonomi och bondeoffer: en vänbok till Jan Lindegren, ed. Peter Ericsson et. al. (Uppsala: Uppsala universitet 2013); Andreas Åkerlund, "The Impact of Foreign Policy on Educational Exchange: The Swedish State Scholarship Program, 1938-1990," Paedagogica Historica 50 no. 3 (2014).

5 For the establishment of the Enlightenment Board see Andreas Åkerlund, Mellan akademi och kulturpolitik: Lektorat i svenska språket vid tyska universitet 1906-1945 (Uppsala: Uppsala universitet 2010), 135-42.

6 See Akerlund (2013) for a detailed account on how the system was established and for the social composition of the scholarship holders in 1938-1957.

7 Copy of a letter from Kungl. Maj:t [Royal Majesty] to statskontoret [the State Treasury] September 8, 1938, I 798, UD [Foreign Ministry] 1920 års dossiersystem, RA [Riksarkivet, National Archive, Stockholm].

8 See documents in I 807, UD 1920 års dossiersystem, RA. 
This program became a template for the manner in which Sweden would conduct international exchange until the 1970s. A central feature is the diplomatic character of the program. Because the program was based on reciprocity, the countries selected either already offered scholarships to Swedish citizens or they were of special interest for the Swedish government in that one could expect future reciprocity from them. This reciprocity also meant that foreign authorities recommended candidates for Swedish scholarships and a Swedish committee recommended Swedish candidates for scholarships offered by foreign countries.

This situation was short-lived; the outbreak of the Second World War in September 1939 complicated exchange activities. Funds were assigned for scholarships through the entire war, but on a much smaller scale and in many cases the scholarships assigned were used as economic aid for academics stranded in Sweden as a result of the war. When more systematic exchange activities were resumed after 1945, they were so in a very different political and organisational setting. In 1945, the Swedish Institute for Cultural Exchange (the name was later changed to Swedish Institute) was established as a joint venture between the Swedish state and private interests, mainly Swedish companies. The mission of the SI was to propagate Sweden and Swedish culture abroad and further international cultural exchange. This changed the general organisation of Swedish public diplomacy as information activities directed to foreign publics were from that point detached from the state bureaucracy and transferred to this new semi-state organisation. ${ }^{9}$

This reorganisation also affected academic exchange. The scholarship program which had until that point been funded and administered by the Ministry for Foreign Affairs was successively transferred to SI. Although the ministry retained the right to make recommendations for a number of scholarships until 1957, from day one SI was solely responsible for the day to day organisation of exchange, including managing the payment of scholarships and travel grants.

Before continuing with the SI exchange programs, it is important to understand the organisational setting in which SI was located between 1945 and 1970. Co-founded and co-financed by both state and private interests, SI was a typical public diplomacy organisation of its time. With the memories of the Second World War still fresh in the minds of Swedish citizens, the detachment from the state administration was deemed necessary in order to avoid engendering the impression of, as Nikolas Glover states "yet another official crude propaganda machine". ${ }^{10}$ The institute was to be a non-political institution, dedicated to information and enlightenment rather than state-controlled propaganda. Therefore, SI was to a certain extent independent from the government administration, although it maintained a close collaboration with the Ministry for Foreign Affairs and other relevant state agencies. The funding of the institute's activities however came mainly from government grants. Although the organisational ideal was for member fees and private donations to constitute an equal part of the institute's budget this was never the case; state funding between 1945 and 1970 always exceeded private contributions by a ratio of between $1: 2$ and 1:6. ${ }^{11}$

9 See Nikolas Glover, National Relations: Public Diplomacy, National Identity and the Swedish Institute 1945-1970 (Lund: Nordic Academic Press 2011) for a general description of the history of the Swedish Institute until 1970.

10 Glover (2011), 33.

11 Glover (2011), 110. 


\section{State-funded exchange in a semi-state institution 1945-1970}

What did this new institutional setting mean for scholarly exchange? First of all it is important to stress that it took time for SI to establish something that could be called normal academic exchange. This was due to the unclear political situation directly after the Second World War, the broken state of many European academic institutions and networks paired with the establishment of the completely new institute, the Swedish Institute, which was looking to define its particular role. In the years following the war, the exchange activities of the institute to a large extent consisted of aid to foreign academics, mainly from Germany and Austria, who were invited to Sweden to establish contact with their colleagues after more than a decade of isolation. This exchange was partly financed through the Swedish government's aid programs to post-war Europe, which is the main reason for the relative high rate of exchange in 1945/46. Once this aid ceased in 1949, the exchange program consisted only of bilateral scholarships offered to a number of Western European countries as well as Canada, Argentina, Brazil and Japan. An interesting case was the Federal Republic of Germany, which was included in the program from 1949. These scholarships were not a part of the ordinary government grant for academic exchange, but were paid for by the Swedish Committee for International Aid (Svenska kommittén för internationell hjälpverksamhet), and thus were a continuation of the short-term scholarships offered to Germans directly after the war. ${ }^{12}$ It was not until 1953/54 that exchange with West Germany was financed in the same way as with other countries.

The bilateral program maintained a special position in the budget of the SI in the 1950 s and 1960s as it was not financed by the government grant from the Ministry for Foreign Affairs which financed other SI activities such as information brochures, expositions and so forth. These scholarships were instead paid for by the Ministry for Ecclesiastical and Educational Affairs. ${ }^{13}$ This detail is interesting because it underlines how academic exchange sits at the intersection of foreign policy and public diplomacy on the one hand and education and science on the other.

The system of bilateral scholarships expanded slowly during the 1950s as more and more Western European countries began taking part in SI exchange programs. The largest expansion however began in 1960 when exchange with the Soviet Union was initiated. This, in turn, opened the door for bilateral exchange regulated through so-called cultural programs - in practice bilateral cooperation agreements - with the other Eastern European countries. ${ }^{14}$ This expansion of the system towards the Warsaw Pact should be understood as part of the Swedish policy to normalise relationships with communist Eastern Europe, especially the Soviet Union. ${ }^{15}$

12 See SI, Verksamhetsberättelse 1949/50, 35, BVII, vol. 1, Hemmamyndigheten, Svenska Institutet, RA.

13 See for instance SI, Verksamheten 1952-53, 61-62, BVII, vol. 1, Hemmamyndigheten, Svenska Institutet, RA.

14 These agreements contained detailed accounts on the kind of exchange (student, lecturer, etc.), but also the number of exchange months available. Agreements are found in F9, vol. 1-18, Hemmamyndigheten 2, Svenska Institutet, RA.

15 The Soviet Union wanted to establish cultural exchange with Sweden since the 1950s, but the signing of a Soviet-US agreement for cultural cooperation was the first time Swedish authorities gave in to the Soviet demands. See Åkerlund (2014), 401-2. 
Similar to the extension of scholarships to West Germany one decade earlier, the Soviet exchange, and later "cultural exchange with certain countries" - a euphemism for exchange with communist Eastern Europe - represented a special post in the budget. Soviet exchange scholarships were financed through the Ministry for Foreign Affairs instead of the Ministry for Ecclesiastical and Educational Affairs. ${ }^{16}$ This situation persisted until the budgetary year 1967/68, where scholarship exchange with Eastern Europe was normalised in a financial sense, that is: paid for through the regular state grants.

From 1945 until the beginning of the 1970s bilateral scholarships financed through the Ministry of Education were the dominate form of scholarly exchange. New exchanges were initiated with special funds, but once the reciprocity was deemed stable, the scholarship costs were transferred and included in the standard state grants. Although the SI was a joint venture between the Swedish state and private actors, the scholarship program was almost exclusively financed through state grants. ${ }^{17}$ The decision about which countries would be part of bilateral exchange was thus deferred to the government and the Ministry for Foreign Affairs. The main rationale behind this decision was the same as in 1938, in that the main purposes of the scholarships were for establishing contacts and improving the knowledge and image of Sweden abroad. Needless to say, this bilateral organisation of exchange determined how the group of incoming scholars was composed. There cannot be much flexibility in a system where a certain number of scholarships are offered to a certain country and where this country in turn is allowed to assign the holders. The bilateral organisation of scholarships also benefitted larger countries, since they had the financial muscle to offer more scholarships. A financial evaluation from 1964/65-1968/69 shows that the largest part of the scholarship budget, 13 per cent of the grand total for these years, was designated for exchange with the Soviet Union, followed by France (8 per cent), Great Britain and Italy (7 per cent each).$^{18}$ Exchange with the United States of America was during this period not financed through the Swedish Institute, but left to the Sweden-America and the American-Scandinavian Foundations. This did not change until the establishment of the Guest scholarship program in $1973 .{ }^{19}$

\section{Unilateral educational support: The Guest scholarship program}

The Swedish Institute was reorganised in 1970 and transformed from a state-private joint venture into a state-financed, but organisationally independent, foundation. This was the result of an increasing ideological divide. The founding companies wanted returns on their investments in the institute whereas the radicalisation of culture in the 1960 s resulted in the idea that cultural production should stand free from, if not oppose, capitalist market ideology. The reorganisation was a way for the state to resolve this conflict. The decision in favor of a foundation instead of a state agency

16 See for instance SI, Svenska institutet 1960-61, 31-32 and 74; SI, Svenska Institutet 1961-62, 48-49 and 76, BVII, vol. 2, Hemmamyndigheten, Svenska Institutet, RA.

17 The exception is six scholarships for Chilean engineers donated by Swedish companies active in Chile and awarded between 1946 and 1949.

18 SI, "Analys av verksamheten 1964/65-1968/69. Etapp I: Fördelning av resurser på finansiärer, media, länder och ämnen," (internal report from the Swedish Institute, 1970), 17 and diagram 7.8.

19 For the relationship between the SI and these foundations see Andreas Åkerlund, "The Nationalization of Swedish Enlightenment Activities Abroad: Civil Society Actors and their Impact on State Politics," in Public Diplomacy in Context, ed. Louis Clerc, Nikolas Glover and Paul Jordan (Leiden: Brill, forthcoming). 
maintained the distance between the institute and the state administration. ${ }^{20}$ This reorganisation also meant that the Ministry of Education no longer paid directly for bilateral scholarships. The SI was however still mainly financed by the Ministry for Foreign Affairs.

In May 1971 the Swedish parliament decided to create a new scholarship program. This was due to the parliament's decision to limit the possibilities for foreign citizens to receive normal student grants. The new program would also make it possible for students without economic assets to study in Sweden. ${ }^{21}$ The shift in argumentation from 1938 is notable. The question was no longer about making the country known abroad, but helping people in need of an education. Similarly, the 1972 inquiry into the internationalisation of Swedish universities, argued that scholarships were a question of international solidarity and responsibility. Sweden had an obligation to educate foreigners in need of a Swedish education. ${ }^{22}$ The Guest scholarships were also organised differently than the bilateral program. The scholarships were unilateral and offered to foreign scholars globally without the involvement of foreign authorities. Applications were therefore directed to SI.

The Guest scholarship program is the main reason for the rise in scholarship costs in the mid-1970s. For the fiscal year of 1975/76 the costs for international exchange of the SI were 35 per cent of the institute's total budget. Of the 4.65 million Swedish crowns spent on all forms of scholarly exchange, guest scholarships constituted 1.26 million or 27 per cent of this total.

The establishment of the large scale Guest scholarship program was however not the only important development in the 1970s. In the 1970s, SI was also assigned smaller programs, funded either directly by the state or by state-initiated foundations. The budgetary year 1978/79 serves as an example of this development. Not only did SI offer long-term and short-term bilateral scholarships for studies and research as well as the guest scholarship program, but they also offered the following special scholarships:

- For Swedish-Finnish exchange financed by the Swedish-Finnish Cultural Foundation.

- For social workers financed by the Council of Europe.

- For Latin American researchers, Portuguese experts and persons from certain developing countries financed by the Swedish International Development Cooperation Agency (SIDA).

- For Vietnamese researchers financed by the Swedish Agency for Research Co-Operation with Developing Countries (SAREC).

- For Sweden-American exchange financed by the Bicentennial Swedish-American Exchange Fund of 1976 (1976 års fond för personutbyte mellan Sverige och Förenta Staterna). ${ }^{23}$

20 Glover (2011), 135-38.

21 SI, Verksamheten 1972/73, 27, BVII, vol. 3, Hemmamyndigheten, Svenska Institutet, RA; Ulla Rylander, Stipendier skapar relationer: En uppföljning av Svenska institutets gäststipendiater 1973-1997 (Stockholm: Swedish Institute, 2010), 8.

22 Utbildningens internationalisering: Slutbetänkande från UKÄ:s internationaliseringsutredning, UKÄ-rapport, no. 21 (1974), 149.

23 SI, Verksamhetsberättelse budgetåret 1978/79: Del 1, 25, BVII, vol. 4, Hemmamyndigheten, Svenska Institutet, RA. 
There are two interesting trends visible in this list. One is that the state allowed SI to administer scholarships financed by other state foundations and state agencies. The Swedish-Finnish Cultural Foundation as well as the Exchange Fund of 1976 had been established by the Swedish state in order to promote cultural cooperation with Finland and the US respectively. The Exchange Fund of 1976 is oriented mainly towards "opinion-makers", such as politicians or journalists.

In 1984 another program was added when the institute was handed sole responsibility for a scholarship program for international researcher exchange (stipendier för internationellt forskarutbyte), originally jointly managed by the Swedish National Agency for Higher Education (Universitets- och högskoleämbetet, UHÄ) and the institute. The main aim of this program was to develop the international contacts of Swedish academia, especially with countries other than the US. ${ }^{24}$ Scholarships in the new international program for researcher exchange were primarily intended for younger Swedish academics wishing to spend time at a foreign university and secondarily for inviting foreign academics to Sweden. The program was paid for by the Ministry for Education and the cost was roughly 4.5 billion crowns for the fiscal year $1985 / 86 .{ }^{25}$ This was 25 per cent of the total exchange budget of the Swedish Institute for the year. The Swedish Institute's extended experience in administrating international exchange led to the institute handling externally funded programs, which were not directly paid for through the standard government grant.

The other trend relates to official assistance to developing countries. The Swedish International Development Cooperation Agency (SIDA) had originally developed within SI as the Central Committee for Technical Assistance to Less Developed Countries, but this committee was dissolved in 1961 and replaced by the Board for International Assistance, a state agency which later became SIDA. ${ }^{26}$ Nikolas Glover interprets this as a diversification of tasks in the international arena:

Thus under the aegis of what I would characterise as a general trend toward specia-
lization and professionalization of Sweden's various relations with the international
community, the practices of technical and financial aid to developing countries were
institutionally separated from those of information and cultural exchange. ${ }^{27}$

The institutional separation in the 1960s mentioned by Glover was however blurred during the 1970s as the SI also managed the scholarly exchange financed through official development assistance (ODA) ${ }^{28}$ Around 8.5 per cent (1.89 million of 22.36 million Swedish crowns) of the SI budget for the budgetary year 1978/79 came from

24 SI, Verksamhetsberättelse 1984-85, 32, BIA, vol. 3, Hemmamyndigheten 2, Svenska Institutet, RA.

25 See Prop. 1983/84:107, appendix 5, 122; Prop. 1984/85:100, appendix 10, 375; SI, Verksamhetsberättelse 1985-86, 30-31, BIA, vol. 3, Hemmamyndigheten 2, Svenska Institutet, RA.

26 Per-Åke Nilsson, Svenskt bistånd till den tredje världen: dess uppkomst under 1950-talet: En studie av SIDA:s och NIB:s föregångare: Centralkommittén för svenskt tekniskt bistånd till mindre utvecklade områden (Hammerdal: Hammerdal förlag och reportage, 2004).

27 Glover (2011), 119.

28 The sources use a variety of expressions for aid to "underdeveloped countries" such as development aid (utvecklingshjälp), underdeveloped country-aid (U-landshjälp), technical assistance (tekniskt bistånd) and the like. To facilitate the reading, the technical term "development assistance" or the abbreviation ODA for Official Development Assistance has been used throughout the article. 
this source. ${ }^{29}$ The general development thus focused on the integration of scholarship programs with the aid given to the non-industrialised world. This development was pushed further in 1985, when money from the development assistance budget assured that 50 per cent of the scholarship holders within the guest scholarship program would come from developing countries. ${ }^{30}$ What is visible here is the assumption that education is important for economic and technical development as well as that knowledge and technology transfer through education is a viable way to help the poorer countries in the world.

The general trend from 1970 to the end of the Cold War in 1990 was that a larger and larger portion of scholarship funding was assigned to the SI from other state foundations or state agencies, which led to a diversification of scholarship forms. The reason behind this diversification is of course that the various scholarships functioned differently. Some scholarships were granted for enhancing contacts with a special country, some for the internationalisation of science, and others were seen as important for foreign aid. This neatly illustrates the variety of tasks assigned to public diplomacy institutions in general. The trend away from bilateral and towards unilateral scholarships is also very clear. In the budgetary year $1988 / 89$, SI spent 18.2 million crowns on both long-term and short-term scholarships. Bilateral scholarships, which had been the institutes' main scholarship form in the 1950s and 1960s, comprised only 3.1 million or 17 per cent of this sum. Geographically, the focus had shifted between 1945 and the late 1980s away from exchange with Western Europe. ${ }^{31}$ In a government investigative survey (Statens offentliga utredningar, SOU) from 1988, developing countries and Eastern Europe were mentioned as the two most important areas targeted by SI exchange programs. ${ }^{32}$ This was certainly a result of the changed policies described above, but also of the expanding Nordic integration of exchange through the establishment of the Scandinavian exchange scheme NORDPLUS run by the Nordic Council of Ministers.

European integration was another important factor in this context. In the same investigative survey, the Erasmus program and other EC programs were mentioned as examples of interesting developments on the European level. Although Sweden was not yet a member of the EU, the investigation also pled for a more active Swedish policy within the field of European collaboration in research, education and culture. ${ }^{33}$ Therefore, it seems that the diminished exchange with Scandinavia and other parts of Western Europe was partially due to the transfer of responsibility from national level organisations to international ones.

\section{The early 1990s: Educating Eastern Europe}

The fall of the Berlin wall in 1989 marked the end of the Cold War and the start of a political transition in Eastern Europe from communism to a market-oriented libe-

29 SI, Verksamhetsberättelse budgetåret 1978/79: Del 2, 90, BVII, vol. 4, Hemmamyndigheten, Svenska Institutet, RA.

30 Rylander (2011), 8.

31 See Åkerlund (2014), 407-9.

32 SOU 1988:9, Sverigeinformation och kultursamarbete: Betänkande avgivet av Utredningen om de statliga insatserna inom Sverigeinformationen och kulturutbytet med utlandet (Stockholm: Fritzes, 1988), 332.

33 SOU 1988:9, 229-33 (Nordic cooperation) and 245-47 and 327-28 (European integration). 
ral democracy. These political changes in the near abroad of Sweden were to mark one of the greatest changes for the SI and its various scholarship programs. From 1990 onwards the former communist countries in Eastern Europe became large recipients of Swedish development assistance. In 1990, the parliament decided on an aid and cooperation program for the former communist countries amounting to 1 billion Swedish crowns over two years. ${ }^{34}$ Parts of this program were placed within the Swedish Institute because cultural contacts in general and academic exchange in particular were deemed to play an important role for the transition from communism to democracy. In the early 1990s, the Swedish efforts were mainly directed towards the Baltic Sea area: Estonia, Latvia, Lithuania, Northwestern Russia and Poland.

The Swedish development assistance, and therefore also the educational measures, directed towards this region had four clear objectives. These objectives were to promote common security; to help establish democracy, democratic institutions and democratic values; to aid the establishment of a liberal market economy and to establish a knowledge base on environmental issues and help develop environmental friendly technologies in a region where industry was outdated, inefficient and polluted heavily. ${ }^{35}$ The exchange programs established after 1990 must therefore be understood within this context of technology and value transfer from West to East, from Sweden to its near abroad. This new geographic focus is visible in the economy of the Swedish Institute. The budgetary year 1993/94 serves as an example. In this year 38.8 per cent of the total SI budget was directed towards Central and Eastern Europe alone. ${ }^{36}$

The large investments of the Swedish government for exchange with the formerly Communist Europe hugely impacted the economy of the Swedish Institute. As visible in Figure 1 the amount allocated within what was at this time called SI program 3 (for educational and scientific exchange) more than doubled between 1990/91 and $1995 / 96 .{ }^{37}$ The period not only saw a rise in numbers, but also a shift in the forms of exchange that were organised and financed. This development is visualised in Figure 2 using the SI budgetary year of 1995/96. ${ }^{38}$

34 Prop. 1990/91:100, appendix 5, 6.

35 OECD, Assistance Programmes for Central and Eastern Europe and the former Soviet Union (Paris: OECD, 1996), 51-53. This is a very schematic description. For more detailed accounts see Elisabeth Hedborg, A good Neighbourhood: Sweden's Cooperation with Central and Eastern Europe (UD info May 1998), (Stockholm: UD, 1998) or Elisabeth Hedborg, Europe in Transition: Sweden's Development Cooperation with Central and Eastern Europe (UD info March 2002), (Stockholm: UD, 2002). For environmental aid see Stefan Hedlund, "The Environmental Problems of Eastern Europe and their Implications," in Europe in the 1990s: Papers from the Third U.S.-Scandinavian Seminar for Parliamentarians in Stockholm, Sweden August 12-14 (Gentofte: Erling Olsens Forlag 1991) and for a more critical account, Ragnar E. Löfstedt, "A Review of Sweden's Environmental Aid to Eastern Europe: Criticisms and Possible Solutions," in Environmental Aid Programmes to Eastern Europe: Area Studies and Theoretical Applications ed. Ragnar E. Löfstedt and Gunnar Sjöstedt (Adlershot: Avebury, 1996).

36 SI, Verksamhetsberättelse 1993/94, 14.

37 From roughly 39 million crowns in 1990/91 to 100 million crowns in 1995/96, measured in the price level of 2010. The division of the Swedish Institute activities into different programs occurred in 1970 when the institute was restructured and transformed into a foundation. The name and content of the programs vary over time, but during the first half of the 1990s exchange was maintained as program 3.

38 All information in the following section comes from the yearly report: SI, Verksamhetsredovisning 1995/96, 18-31 unless otherwise indicated. 
Figure 2. SI exchange financing 1995/1996 (by type)

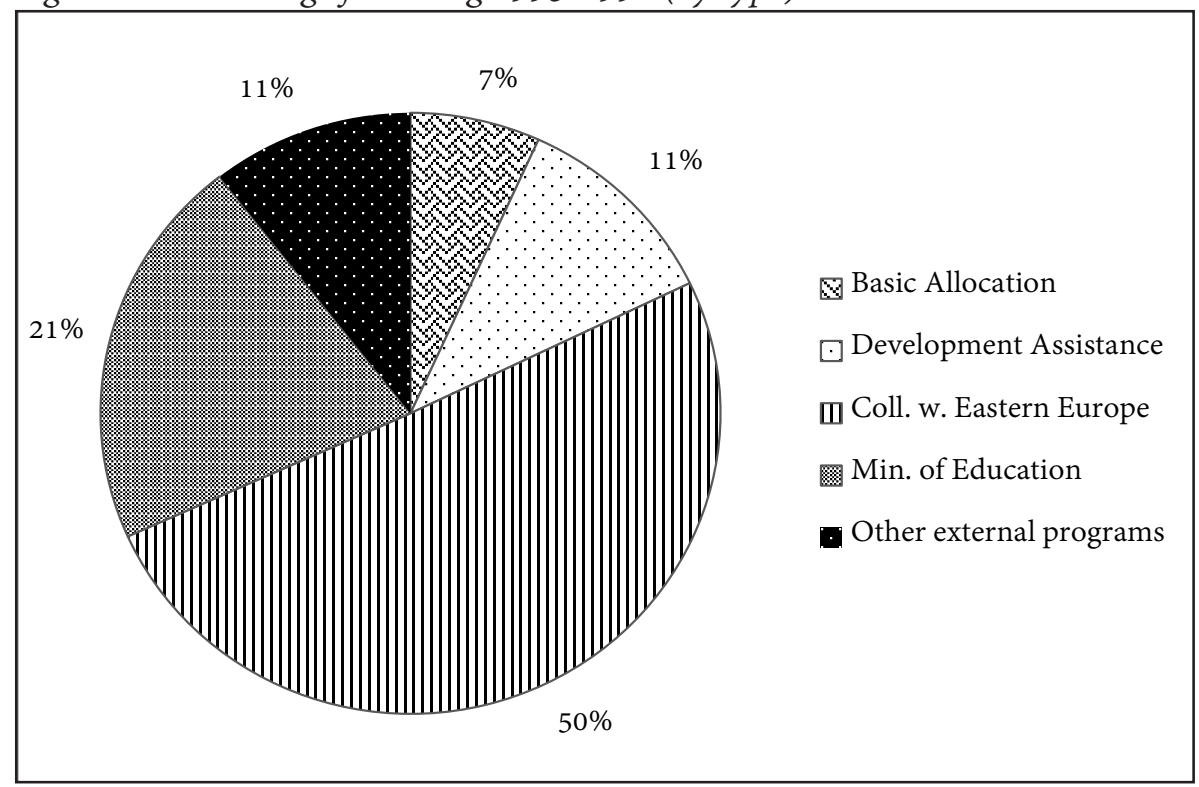

Financing of SI exchange activities for the budgetary year 1995/96. Note: The category "Development Assistance" contains all official development assistance funding except the special programs directed towards Central- and Eastern Europe. These are included in "Coll. w. Eastern Europe". Sources: SI, Verksamhetsredovisning 1995/96; SI, Årsredovisning 1995/96.

Figure 2 neatly illustrates the impact of the new government policy on the exchange budget of the Swedish Institute. Half of the amount spent on exchange consisted of resources for collaboration and exchange with the former communist countries in Eastern Europe. This amount was received by the institute through different funding bodies which in turn led to the establishment of a number of new programs especially designed for Eastern Europe. For 1995/96 these were:

- Funds from the Legal, Financial and Administrative Services Agency Kammarkollegiet for a bilateral research collaboration program with Eastern Europe.

- Special funds from the Ministry for Foreign Affairs for collaboration with Eastern Europe (budget line III G 1 and 2) for:

- A special scholarship program for Eastern Europe.

- Collaboration projects between Swedish and Eastern European universities.

- Minor field studies in Eastern Europe.

- Short-term exchanges of experts.

- Funds from the Nordic Council of Ministries for special scholarships to the Baltic States and Northeastern Russia.

The SI basic allocation as well as development assistance from the Ministry for Foreign Affairs (budget lines III D 1 and III C 1-7) financed bilateral and guest scholarship programs. At this point, however, these financial sources, constituted less 
than 20 per cent of the grand total spent on exchange. The trend towards administrating several parallel programs with different target groups and different external financing agencies which had started in the 1970s thus accelerated during the 1990s. Apart from the previously mentioned programs for Eastern Europe, the bilateral and the guest scholarships, the institute also handled the following exchange schemes:

- The international researcher program financed by Kammarkollegiet.

- Scholarships for Icelandic, Canadian and Swedish students for "European studies" financed by the Ministry of Education.

- Scholarships for Chinese and Malaysian students financed by SIDA.

- Travel grants for teachers and school leaders financed by the National Agency for Education.

- Scholarships from the Bicentennial Swedish-American Exchange Fund of 1976.

- Scholarships for Swedish citizens from the Scholarship Foundation for Studies of Japanese Society. ${ }^{39}$

- Collaboration projects between Germany and Sweden joint financed by Kammarkollegiet and the German Academic Exchange Service (DAAD).

The fall of the Berlin wall in 1989 and the following breakdown of communist Europe clearly changed the geographic focus of the Swedish Institute. The turn towards Eastern Europe led to a remarkable rise in economic resources for exchange, which in turn resulted in a sharp rise in the number of scholarship holders as well. There were 677 long-term scholarship holders for 1995/96 according to the yearly report compared to 277 scholarship holders in $1988 / 89 .{ }^{40}$ In $1995 / 96$ a staggering 120 persons came to study and research in Sweden through the special scholarship program for Eastern Europe alone. The same year, 205 scholarship holders were designated within the guest scholarship program, open for persons from the entire world. The yearly reports do not provide more information than numbers, but since the large programs directed towards Eastern Europe had a very special focus, namely to enhance democracy and to support the transition towards a market economy and environmental friendly technologies, it is not surprising that persons within the fields of political science, economy or certain branches of natural sciences and engineering constituted the majority of scholarship holders within the programs.

On another level the heavy investment of the Swedish state in scholarship programs aiming at certain geographic areas was a continuation of the earlier development. This trended clearly towards more and more parallel programs, each one funded through yet another foundation or state agency and targeting a certain group or geographic area. This also meant that the classic diplomatic principle of bilateralism, which had been so important during the early years, was abandoned in favor of

39 This is a small state-initiated foundation similar to the Swedish-Finnish Cultural Foundation. The foundation was created using a small portion of the profit from selling half of the Swedish embassy property in Tokyo in 1987. See the foundation homepage for a description of its history: The Scholarship Foundation for Studies of Japanese Society, "Om Japanstiftelsen, "Japanstiftelsen, http:// www.japanstiftelsen.se/display.asp?apid=8 (accessed September 15 2014).

40 These numbers are an aggregate of the numbers for long-term programs presented in SSI, "Resultatanalys verksamhet 1987/88-1991/92," (internal report from the Swedish Institute, 1992) and SI, Verksamhetsredovisning 1995/96, 18-24. 
unilateral solutions where the SI was solely in control of the specific designation, in accordance with the general lines drawn up by each funding body.

\section{8-2010: A state agency in favor of markets, democracy and security} In 1997, the Swedish state decided to reorganise the Swedish Institute once again. On January 1st, 1998 the foundation was transformed into a government agency. ${ }^{41}$ This decision broke with the long tradition of attempting to maintain the SI a relatively independent organisation - one of the aims at its founding in 1945. The institute however continued to constitute a line on the budget of the Ministry for Foreign Affairs. The transformation into a government agency however changed the way the institute recorded the use of allocated funds. Thus, from 1998 onwards it is not possible to specify exactly which funds went to certain scholarship programs. Any numbers for this epoch will therefore by necessity be calculated on a more aggregate level. One such aggregate presentation for the years 2000-10 is visible in Figure 3, where the general budget of the SI has been divided roughly along the same lines as Figure 2. The most striking feature in this figure is the large sums designated towards work in and collaboration with Eastern Europe.

Figure 3. SI general funding 2000-2010 by source/designation

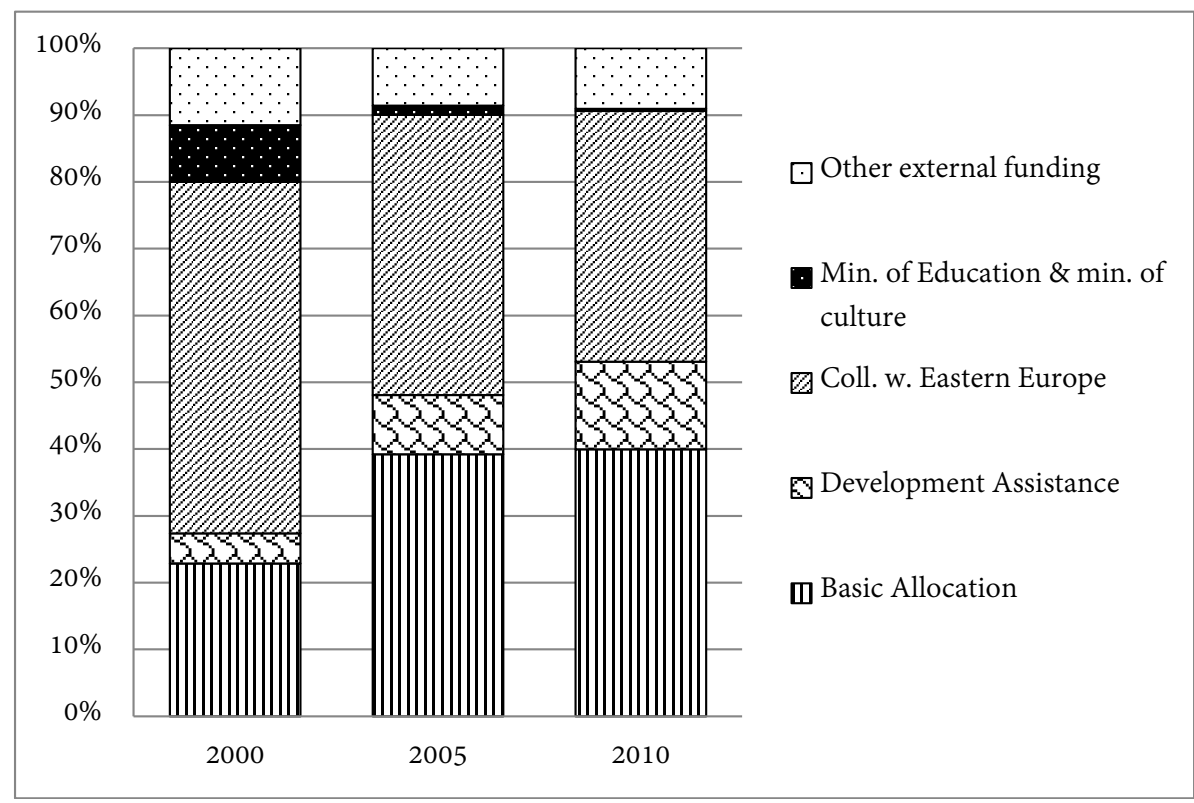

The funding of the Swedish Institute 2000, 2005 and 2010 by source. Note: The category "Development Assistance" contains all official development assistance funding except the special programs directed towards Central and Eastern Europe. These funds are included in "Coll. w. Eastern Europe". Sources: SI, Årsredovisning 2000; SI, Årsredovisning 2005; SI, För Sverige i världen: Svenska Institutets årsredovisning 2010. 
The dominance of Eastern Europe is partly a continuation of the development assistance and collaboration programs of the early 1990s, but mainly the result of a government program for occupational and economic growth. In June 1996 the Swedish parliament decided on the so called Occupational Bill (Sysselsättningspropositionen) aiming at reducing unemployment by 50 per cent until the year 2000 . This bill suggested an active economic policy for economic and occupational growth in combination with an expanded and deepened collaboration in the Baltic area as the emerging markets in this area were of great importance for Swedish export. ${ }^{42}$ This bill was to have an important impact on the Swedish Institute, especially through the so-called Baltic Billions program (Östersjömiljarderna). The aim of this program was to "stimulate economic exchange, growth and employment in Sweden and the Baltic region, and to strengthen the position of Swedish companies in the region." 43 The first billion was allocated in 1996 and the second in 1998; both were to be used over a five year-period, which meant that the entire sum needed to be spent by $2003 .{ }^{44}$

A large part of the Baltic Billions program was transferred to the SI for exchange and collaboration activities with the neighboring countries around the Baltic Sea. The result was the Visby program, which is still in existence. At its establishment in 1997 the Visby program was a broad program for academic collaboration and exchange with Estonia, Latvia, Lithuania, Poland and northwestern Russia (most notably St. Petersburg and Kaliningrad) which financed both individual exchange as well as institutional collaborations in the region. The Visby program was financed with 120 million crowns over the Baltic Billions. It was succeeded by the New Visby program in 2000, which in turn received 90 million crowns from the same source. The total budget of these two programs was 210 million Swedish crowns, which means that a total of 21 per cent of the first Baltic Billion was invested in academic cooperation and educational exchange. ${ }^{45}$ There was also a parallel 100 million crowns program, the Baltic scholarship program, directed at the same geographic region and financed jointly by the Ministries of Employment (80 per cent), Education (10 per cent) and Foreign Affairs (10 per cent). This program was also a result of the occupational bill as indicated by the large sums provided by the Ministry of Employment. ${ }^{46}$

The New Visby program was not entirely financed through the Baltic Billions, but was partly a separate assignment from the government with an extra budget of 60 million Swedish crowns, in addition to the 90 million already granted over the Baltic Billions. The program ran over a period of one and a half years and applied to the same geographical area as the old programs, but was later extended to include Ukraine and Belarus. It also included the possibility to conduct exchange within

42 Prop. 1995/96:222, Vissa åtgärder för att halvera arbetslösheten till år 2000, ändrade anslag för budgetåret 1995/96, finansiering m.m., section 5.1.

43 The Swedish Government, "Baltic Billion Funds: The Baltic Billion Funds - promotion of trade and industry in the Baltic region," Regeringskansliet, http://www.government.se/sb/d/3095 (accessed September 15 2014).

44 For the financial and political background see: Förslag till riksdagen 2001/02: RR14: Riksdagens revisorers förslag angående den ekonomiska redovisningen av Östersjömiljarderna, 17-22, or: Ds 2002:46, Östersjöprogram för framtiden: Studie gällande behov av fortsatta särskilda statliga insatser för att främja näringslivsutvecklingen i Östersjöregionen efter år 2003, 89-92.

45 SI, Årsredovisning 1997, 24; SI, Årsredovisning 2000, Appendix 3, 16-21; Boston Consulting Group, "Utvärdering av den första Östersjömiljarden: Del II (appendix 2: utvärderingar)," 2004, 107, 444.

46 SOU 2000:122 (bilaga), Att utveckla samarbetet med Central-och Östeuropa: Utvärdering av utvecklingssamarbetet (Stockholm: Fritzes 2000), 55-56. 
secondary education. ${ }^{47}$ The program was made permanent in 2002 and has since then been financed through state grants. It has however made an interesting journey through the state budget. In 2002 it was financed through the two-year special program "Collaboration with Central and Eastern Europe", located within the budget for development assistance. ${ }^{48}$ By 2007 , however, the Visby program ceased to be a part of the ODA budget and in 2010 it was listed in the budget for general international cooperation, which includes Swedish contributions to international organisations such as the UN and the Nordic Council of Ministers, to international peacekeeping and to research on security policy and international peace. ${ }^{49}$ In less than 15 years, the program thus moved from being a part of the stimulation of growth, employment and economic exchange to being financed by development assistance, to being classified as a part of Swedish security policy financed through the money designated for international collaboration.

Besides the various Visby programs there were additional programs directed towards formerly communist Europe. The special scholarship program from the early 1990s was renamed Eastern Europe scholarships (Östeuropastipendier) in 1998. This program was directed to countries outside the Baltic area, with most applicants coming from Bulgaria, Romania and the parts of Russia not eligible for the Visby program..$^{50}$ The program was abandoned in 2006 . The institute also administered various scholarship programs directed towards Eastern Europe on behalf of SIDA. Examples include the program directed towards Caucasus and Moldova (1997-2005) and the MSEE program (Master in Sweden for Eastern Europe in 2006-2010). ${ }^{1}$ The intensified exchange with Eastern Europe which began in the early 1990s was continued during this period and was gradually expanded from its focus on the near abroad around the Baltic to also target more distant areas, such as the Caucasus.

Concurrently, the bilateral scholarship system was slowly dismantled. This old method of conducting exchange, with its roots in the classic diplomatic idea of reciprocity, seems to have lost its relevance as a result of European integration. This is best seen through the bilateral cultural programs with Eastern Europe, which were normally cancelled as these countries entered the European Union..$^{52}$ In 2005, bilateral exchange was carried out with 12 different countries, which sent a total of 43 students or scholars on long-term exchanges to Sweden. ${ }^{53}$ In 2010, these numbers had fallen to only three different participating countries and 24 scholarship holders, of which 18 were from China alone. ${ }^{54}$

47 See SI, Årredovisning 2000, Appendix 3, 22-26 for the New Visby-program.

48 Prop. 2002/03:1, Förslag till statsbudget: Utgiftsområde 7, 81-98; SI, Årsredovisning 2002, 66.

49 Krister Eduards, "Visbyprogrammet - ny uppdragsformulering," (internal report for the Ministry for Foreign Affairs, October 15, 2006); Prop. 2009/10:1, Förslag till statsbudget: Utgiftsområde 5, 35-36; SI, För Sverige i världen: Svenska Institutets årsredovisning 2010, 80.

50 SI, Årsredovisning 2006, 42.

51 SI, Årsredovisning 1998, 25; SI, Årsredovisning 2005, 31; SI, För Sverige i världen: Svenska Institutets årsredovisning 2010, 55.

52 An example is 2005 when the agreements with Poland, Slovakia and the Czech Republic were cancelled for this reason. SI, Årsredovisning 2005, 21.

53 The scholarship holders came from Bulgaria, China, France, Germany, Hungary, Italy, Japan, Romania and Russia. India, Switzerland and the Ukraine did not take advantage of the bilateral agreements this year. SI, Arsredovisning 2005, 20-21, 27, 42, 56.

54 The countries were China, Italy and Japan. SI, För Sverige i världen: Svenska Institutets årsredovisning $2010,27,32,50$. 
A similar development is seen within the guest scholarship program, which is nominally open for applicants from the entire world. The cutting of funds for general exchange did however bias the program towards scholarships financed by official development assistance directed at countries receiving such assistance (ODA countries). This process is clearly visible from 1999 when the Swedish Institute started including detailed accounts of scholarship holders' origins in the yearly reports. The total amount of persons entering Sweden on a guest scholarship in 1999 was 111 of which 102 came from ODA countries outside Europe. This meant that only nine persons from Western Europe and North America were awarded scholarships, which is explained by the cutting of funds "for this part of the program", that is the part not financed by development assistance..$^{55}$ In 2005, SI granted 16 guest scholarships for non ODA countries and 38 scholarship holders from this category entered Sweden that year. This can be compared to 45 granted holders from ODA countries and the 96 persons from this category active in the country. ${ }^{56}$ The total cost was 8460000 Swedish crowns of which 81 per cent or 6861000 went to ODA scholarships. ${ }^{57}$

\section{Conclusions}

Diversification is the word which best describes the general development of exchange financing through the Swedish Institute. Bilateral exchange starting in 1938, followed by the guest scholarship program in 1972, the aid programs towards Eastern Europe in the 1990s and the Visby-program after 1997 all had different aims, rationales and funding schemes. To these the various assignments from other state agencies and foundations can be added, which were normally directed towards a certain geographic area. Most of these seem to have been short-term programs, especially those financed by development agencies. In spite of the variety of programs, it is possible to identify three main sources of funding for scholarly exchange through the SI.

- The Ministry for Foreign Affairs has been a constant funder of the SI, although not always of their exchange programs.

- The Ministry for Education has been important during two distinct periods: 1945-70 (bilateral scholarships) and 1985-2000 (the international researcher program).

- Development assistance (either directly or through the various state aid agencies) has been a constant since the 1970s.

The first question posed at the beginning of this article was: why does the state sponsor exchange at a given time? As visible in this article there are several answers to this question depending on the time period and the intention behind the scholarships.

The entrance into bilateral exchanges, starting in the late 1930s was motivated

55 SI, Årsredovisning 1999, 26-27. No persons from Eastern Europe were granted guest scholarships as there were at least two special scholarship programs for Eastern Europeans this year. Therefore, the total number of scholarships financed through development assistance is likely much higher.

56 The difference between the numbers of granted versus utilised scholarships is due to the budgetary year not corresponding to the academic year. This means that scholarships granted in 2004 were also present in the budget of 2005 .

57 SI, Årsredovisning 2005, 24-26 and 33-34. 
by the Enlightenment Board who felt it was necessary to make the country known abroad. Organisationally, it was an adaption of the existing international system, where bilateral and reciprocal exchange was the standard. Originally paid for by the Ministry for Foreign Affairs, after the Second World War exchange was the only part of the SI budget coming from the Ministry for Ecclesiastical and Educational Affairs. This is interesting as it positions academic exchange between both foreign policy and public diplomacy (through the organisational belonging) and educational and research policy (through the funding body). Another motive is what can be referred to as using exchange as an ice-breaker, especially during the Cold War when exchanges with the Soviet Union and other Warsaw pact countries were initiated. Here exchange was seen as a part of a larger strategy to use cultural contacts for normalising relationships between states.

From early on, scholarly exchange was also part of foreign aid and as such thought of as suitable for the one-sided transfer of knowledge and values from the giving to the receiving countries. The earliest example is the scholarships for occupied (and later West) Germany directly after the Second World War. But it was during the 1970s, when SI started to run programs for SIDA that exchange really became a part of Swedish development assistance. From that point scholarships were funded with ODA money in at least two ways. One was that SI was given the responsibility for special programs from SIDA or other aid organisations such as the Swedish Agency for International Technical and Economic Co-operation (BITS) or SAREC. The other was to partly finance the broader guest scholarship program through development assistance which began in 1985 and has continued since.

One surprising finding is that the general idea of promoting exchange for the internationalisation of science was championed by the SI at a fairly late point. Of the programs treated in this article, it was only the international researcher program (1984-2000), which was primarily motivated by internationalisation. This is however not surprising when considering that state funds for internationalisation of science were likely distributed through other organisations than the SI, which has the specific mission of representing Sweden internationally. How - that is through which agencies and through what parts of the budget - the state has historically funded the making of international contacts for research is however a question, which should receive further scholarly attention. The most recent motivation behind funding academic exchange is also one of the most interesting motivations. The Visby program clearly originates within a government program for employment and economic growth in Sweden, which aimed to stimulate economic exchange and thereby to strengthen the position of Swedish companies in the countries around the Baltic. The fact that 22 per cent of the first Baltic Billion was directed to academic cooperation and exchange shows that higher education and research was seen as an important sector for stimulating trade and economic growth. One open question for the future is whether this policy has favored certain subjects or universities within Swedish higher education and research and if so, which ones.

Although it is possible to identify various reasons or policies behind funding exchange, it is almost impossible to reduce exchange through the SI at any given time to a single rationale. Even when looking at the various post-1990 programs towards Eastern Europe, they all carried different rationales. Some were reciprocal and regulated in bilateral cultural agreements; some were paid for through the development 
assistance part of the budget and others were part of the Visby program which originated in an active economic growth policy. However, all exchange programs were a part of the basic mission of the institute: to represent Sweden abroad. What this article has shown is the variety of ways in which the Swedish Institute has organised and funded this representative task. 


\section{References}

\section{Archival sources}

Riksarkivet, Stockholm [Swedish National Archives]

Utrikesdepartementets arkiv [Archive of the Ministry for Foreign Affairs].

Svenska institutets arkiv [Archive of the Swedish Institute].

\section{Printed sources and literature}

Bitumi, Alessandra. "Building Bridges across the Atlantic: the European Union Visitors Program: A Case Study for Public Diplomacy and the Transatlantic Relationship in the 1970s." The International History Review 35 no. 5 (2013), 925-42.

Boston Consulting Group. "Utvärdering av den första Östersjömiljarden: Del II (appendix 2: utvärderingar)." 2004.

$\mathrm{Bu}$, Liping. "Educational Exchange and Cultural Diplomacy in the Cold War." Journal of American Studies 33 no. 3 (1999), 393-415.

Ds 2002:46. Östersjöprogram för framtiden: Studie gällande behov av fortsatta särskilda statliga insatser för att främja näringslivsutvecklingen i Östersjöregionen efter år 2003. Stockholm: Fritzes, 2002.

Eduards, Krister. "Visbyprogrammet - ny uppdragsformulering." Internal report for the Ministry for Foreign Affairs, October 15, 2006.

Förslag till riksdagen 2001/02: RR14: Riksdagens revisorers förslag angående den ekonomiska redovisningen av Östersjömiljarderna.

Glover, Nikolas. National Relations: Public Diplomacy, National Identity and the Swedish Institute 1945-1970. Lund: Nordic Academic Press, 2011.

Hedborg, Elisabeth. A good Neighbourhood: Sweden's Cooperation with Central and Eastern Europe (UD info May 1998). Stockholm: UD, 1998.

Hedborg, Elisabeth. Europe in Transition: Sweden's Development Cooperation with Central and Eastern Europe (UD info March 2002). Stockholm: UD, 2002.

Hedlund, Stefan. "The Environmental Problems of Eastern Europe and their Implications." In Europe in the 1990s: Papers from the Third U.S.-Scandinavian Seminar for Parliamentarians in Stockholm, Sweden August 12-14, 19-26. Gentofte: Erling Olsens Forlag, 1991.

Kim, Terri. "Shifting Patterns of Transnational Academic Mobility: A Comparative and Historical Approach." Comparative Education 45 no. 3 (2009), 387-403.

Löfstedt, Ragnar E. "A Review of Sweden's Environmental Aid to Eastern Europe: Criticisms and Possible Solutions." In Environmental Aid Programmes to Eastern Europe: Area Studies and Theoretical Applications, edited by Ragnar E. Löfstedt and Gunnar Sjöstedt, 63-84. Adlershot: Avebury, 1996,

Medalis, Christopher. "The Strength of Soft Power: American Cultural Diplomacy and the Fulbright Program during the 1989-1991 Transition Period in Hungary." AUDEM: The International Journal of Higher Education and Democracy 3 (2012), 144-163.

Mulcahy, Kevin V. "Cultural Diplomacy and the Exchange Programs: 1938-1978." The Journal of Arts Management, Law, and Society 29 no. 1 (1999), 7-28.

Nilsson, Per-Åke. Svenskt bistånd till den tredje världen: dess uppkomst under 1950-talet. En studie av SIDA:s och NIB:s föregångare: Centralkommittén för svenskt tekniskt bistånd till mindre utvecklade områden. Hammerdal: Hammerdal förlag och reportage, 2004. 
OECD. Assistance Programmes for Central and Eastern Europe and the former Soviet Union, Paris: OECD, 1996.

Prop. 1983/84:107 (Om forskning).

Prop. 1984/85: 100 (Förslag till statsbudget för budgetåret 1985/85).

Prop. 1990/91:100 (Förslag till statsbudget för budgetåret 1991/92).

Prop. 1995/96:222 (Vissa åtgärder för att halvera arbetslösheten till år 2000, ändrade anslag för budgetåret 1995/96, finansiering m.m.).

Prop. 2002/03:1 (Budgetpropositionen för 2003).

Prop. 2009/10:1 (Budgetpropositionen för 2010).

Rylander, Ulla. Stipendier skapar relationer: En uppföljning av Svenska institutets gäststipendiater 1973-1997. Stockholm: Swedish Institute, 2010.

SOU 1988:9, Sverigeinformation och kultursamarbete: Betänkande avgivet av Utredningen om de statliga insatserna inom Sverigeinformationen och kulturutbytet med utlandet. Stockholm: Fritzes, 1988.

SOU 2000:122 (bilaga). Att utveckla samarbetet med Central-och Östeuropa: Utvärdering av utvecklingssamarbetet. Stockholm: Fritzes, 2000.

Svenska Institutet (SI). "Analys av verksamheten 1964/65-1968/69. Etapp I: Fördelning av resurser på finansiärer, media, länder och ämnen.” Internal report from the Swedish Institute, 1970.

Svenska Institutet (SI). "Resultatanalys verksamhet 1987/88-1991/92.” Internal report from the Swedish Institute, 1992.

Svenska Institutet (SI). Verksamhetsberättelse 1993/94.

Svenska Institutet (SI). Verksamhetsredovisning 1995/96.

Svenska Institutet (SI). Årsredovisning 1997.

Svenska Institutet (SI). Årsredovisning: Verksamhetsåret 1998.

Svenska Institutet (SI). Årsredovisning 1999.

Svenska Institutet (SI). Årsredovisning 2000.

Svenska Institutet (SI). Årsredovisning 2005.

Svenska Institutet (SI). Årsredovisning 2006.

Svenska Institutet (SI). För Sverige i världen: Svenska Institutets årsredovisning 2010. The Scholarship Foundation for Studies of Japanese Society. "Om Japanstiftelsen." Japanstiftelsen. http://www.japanstiftelsen.se/display.asp?apid=8 (accessed September 15 2014).

The Swedish Government. "Baltic Billion Funds: The Baltic Billion Funds - promotion of trade and industry in the Baltic region." Regeringskansliet. http://www. government.se/sb/d/3095 (accessed September 15 2014).

Utbildningens internationalisering: Slutbetänkande från UKÄ:s internationaliseringsutredning. UKÄ-rapport 21, 1974.

Åkerlund, Andreas. Mellan akademi och kulturpolitik: Lektorat i svenska språket vid tyska universitet 1906-1945. Uppsala: Uppsala universitet, 2010.

Åkerlund, Andreas. "Utrikespolitik och internationellt utbyte: Svenska statsstipendier som offentlig diplomati 1938-1957.” In Allt på ett bräde. Stat, ekonomi och bondeoffer: en vänbok till Jan Lindegren, edited by Peter Ericsson, Fredrik Thisner, Patrik Winton and Andreas Åkerlund, 391-404. Uppsala: Uppsala universitet, 2013.

Åkerlund, Andreas. "The Impact of Foreign Policy on Educational Exchange: The Swedish State Scholarship Program 1938-1990.” Paedagogica Historica 50 no. 3 (2014), 390-409. 
Åkerlund, Andreas. "The Nationalization of Swedish Enlightenment Activities Abroad: Civil Society Actors and their Impact on State Politics." In Public Diplomacy in Context, edited by Louis Clerc, Nikolas Glover and Paul Jordan. Leiden: Brill (forthcoming). 